\title{
An Analysis of Corruption and Inefficiency in Nigerian Public Service: Islamic Point of View
}

\author{
Mustapha Sidi Attahiru, PhD \\ Department of Business Administration \\ Faculty of Management Sciences \\ Usmanu Danfodiyo University Sokoto, Nigeria
}

\begin{abstract}
:
This research aims to determine the effect of corruption on Inefficiency in the Nigerian public sector from Islamic point of view. This is because corruption has adversely affected the socio-cultural, political and economic development of Nigeria.The survey was conducted at Sokoto State Nigeria. Primary data was collected and SmartPLS 3 version was used for the analysis. 150 questionnaires were distributed to the senior staff of Local Government Service Commission, Sokoto, but only 96 were used for the analysis. The study found that there is significant relationship between corruption and inefficiency in Nigeria's public service. The study also established that inefficiency that bedevilled the public service is as a result of corruption. This research is significant as there is dearth of literature on Islamic approach linking inefficiency to corruption in Nigeria. While this paper sets the stage, there is however, the need for future research.
\end{abstract}

\section{Introduction}

Public service is a department or body of government that is responsible for the planning and implementation of policies of government (Arowolo, 2012; Attahiru, 2021). It plays an important role in the policy of government that includes advising the government technically and professionally based on expertise, knowledge and long service experience, development of programmes and options for the execution of government projects in accordance with the availability of resources, monitoring and evaluation of programmes and on-going projects as well as ensuring the implementation of all government policies for the achievement of set goals and objectives among others (Omisore, 2015). However, the achievement of these goals and objectives in most cases is been defeated by corruption and inefficiency.

Corruption is defined as abuse of entrusted power for private gain (Transparency, 2022). According to the United Nations, corruption is a complex social, political and economic phenomenon that affects all countries. It undermines democratic institutions, hampers economic development and contributes to governmental instability (Nations, 2021). According to Nweke (2019), corruption empowers few privileged individuals to convert what belong to the general public to their personal properties which at the long run results to widespread poverty and poor state of infrastructure amongst other societal problems. Salihu (2020) asserted that corruption by the Nigeria's public officers arises in the process of carrying out their mandates, it manifests in activities such as bribery, embezzlement, fraud, forgery, pilfering and inflation of contracts and procurements among others. Ijewereme (2015) said that corruption in Nigeria's public service manifests in the form of misappropriation, kickback, over invoicing, bribery, embezzlement, tribalism, nepotism, money laundering, outright looting of the treasuring, and so on. Nweke (2019) observed that corruption has become a culture to the level that people no longer see corruption as evil in the society and as a result, corrupt public office holders are now highly respected in public functions thereby making it a recurrent decimal in the society. Transparency International viewed that corruption can happen anywhere, can involve anyone and almost happens in the shadow (Transparency, 2022).

In efficiency as defined by Cambridge online dictionary, is a situation in which someone or something fails to use resources such as time, materials, or labour in an effective way. Walyben (2022) highlighted that, the inefficiency in the civil service occurs due to the emergence of corrupt practices that include; politicization 
of the civil service, poor remuneration, lack of skilled manpower, poor human resource management, insufficient materials, use of obsolete materials, inadequate manpower training and inadequate supervision. According to Osawe (2015), the efficiency of the public service is a function of its environment. Therefore, "giving the complexity of the situation where Nigerians are suffering in the midst of many, several questions have been raised on why the public service has thrown away the core values of the public service, neglecting the Bureaucratic rules of the public service, and has not been able to perform effectively towards meeting the needs of the Nigeria citizens? In attempting to find an answer to the above question, many scholars and public stakeholders have argued that the public service has been bedeviled with lots of unfavourable environmental factors such as corruption, favouritism, nepotism, constant political interference and other primordial factors such as geographical, ethnic, cultural and religious affiliation with its constitutional consequence of federal character principle or quota system" (Osawe, 2015,p.46)

However, Islam has a solution to all the aforementioned problems as it covers all aspects of human life. This is because Islam is not only a doctrine of worship but also an integrated system that governs all rules, obligations, values, manners and practices to ensure the integrity and justice between human beings (Ali, Noordin, \& Achour, 2018). In this regard, this study highlights the Islamic point of view on the relationship of corruption with inefficiency in the Nigeria public service. This paper is categorised into five sections; section one is the introduction and section two is the review of the extant literature. Methodology and main findings were discussed in sections three and four respectively, while section five discusses the limitations and direction for future research.

\section{Literature Review}

\subsection{Corruption}

Corruption is one of the major threats to socio-economic and political development of any nation. According to Mohammed (2013), corruption is not an easy task to define as it is a daunting challenging venture. However, Andvig, Fjeldstad, Amundsen, Sissener and Søreide, 2001:4) view corruption as a "complex and multifaceted phenomenon with multiple causes and effects, as it takes on various forms and contexts". They stressed that, one of the difficulties in conceptualizing corruption is that whereas it is not easy to disappear it has a capacity to take on new forms (Andvig et al., 2001). In addition, Tanzi (1998) asserted that the crisis associated with corruption is not difficult to recognize though it is difficult to be defined. Ayobolu (2006) maintain that corruption is one of the reasons for many unresolved problems that have critically hobbled and reduce development in Nigeria. It also remains a long-term major political and economic growth challenge for Nigeria (Nwankwo, 2014). In addition EFCC (2019) confirmed that corruption is a canker worm that has reduced development in all sectors of the Nigerian economy.

Siddiqi (2004) stressed that the Quran mentions the concept of fasad which literally means corruption in many verses and all in negative form. These include: blood shedding (Al-Qur'an, 2:30), destruction of people and crops (Al-Qur'an,2:205), severing the ties of kinship (Al-Qur'an, 47:22), dividing people into classes and discriminating between them (Al-Qur'an, 28:4), giving people less than full measure and wronging them in their goods (Al-Qur'an, 11:85; 26:183), arrogance borne of enormous wealth (Al-Qur'an, 28:77) and sexual perversion (Al-Qur'an, 29:28-30). Arafa (2012) stated that Muslim jurists gave different definition of corruption which include; mischief, abuse, rottenness, decay, decomposition, putrefaction, depravity, wickedness, viciousness, iniquity and dishonesty.

\subsection{Inefficiency}

Islam addresses the issue of inefficiency in all aspects including the public service as it possesses the unique principles in its nature that guides and shapes the behaviours of individuals spiritually and morally (Attahiru, 2021). Public service in Islam is the hierarchically organized body of public officials who work through fixed rules and procedures of shari'ah to realize governmental objectives as expressed in the state policy and programs instructed by the chief executive of Islamic state and all other consultative members of Shura (assembly) (Chandio \& Chandio, 2021). The Islamic administrative principles can be applied in any organization and its impact centre around the managerial practices, employment practices, and training and development of an administrator (Chandio, Iqbal Ameen Brohi, Ali, \& Gadhi, 2019; Salleh \& Mohamad, 2012). 
In fact, for a public officer to be efficient in the conduct of his responsibility, he must put into practice the Islamic ethical traits that design the living structure on basis of honesty, virtuous, morality corruption-free administration, worthiness and steadfastness in one's authority. Al-Quran (3:146) says: "And God loves those who are firm and steadfast." Efficiency is an integral part of Islamic civilization as Islam calls inefficiency as the downfall of civilization, Holy Prophet says: "If the offices were assigned to unworthy people, which would mean the end of this world (Bukhari Narrator, Abu Hurraira)".

\subsection{Conceptual framework}

This section discusses the conceptual framework of this study which is developed under the Islamic approach. Figure 1 shows the research model indicating Inefficiency as dependent variable and corruption as independent variable.

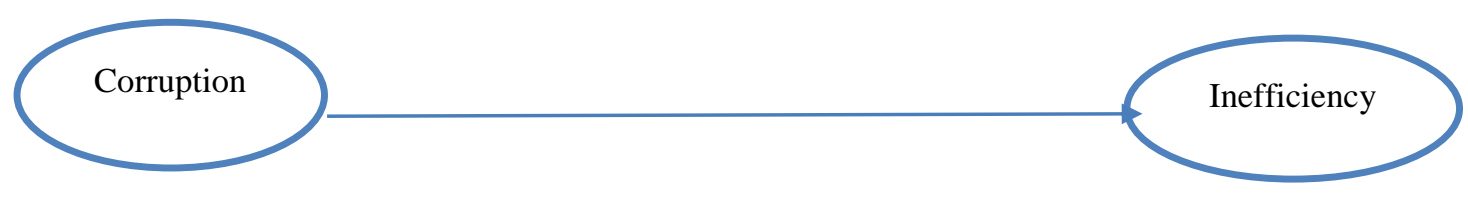

Fig. 1: Conceptual framework

\subsection{Corruption and Inefficiency}

Islam justifiably rejects corruption and inefficiency in public service such as fraud exploitation, favouritism and cronyism in hiring and firing of employees, monopoly, and at the same time encourages justice and prosperity (Muhammad, Yusof, Amin, \& Chowdhury, 2012). Any person entrusted with a leadership position is expected to establish justice, oversee the affairs of his domain, apply the religious teachings among his people throughout his realm and to provide for the needs of his people (Mujahid, 2012). Sultan Muhammad Bello of the Sokoto Caliphate, any person appointed as a leaders in the public service should strive to play it safely since he is going to give the account of his leadership that comprises his actions, words and affairs before Allah (SWT) (Yusuf, 2013)

The Prophet (PBUH) said: "Indeed, the most beloved of people to Allah on the Day of Judgement, and the nearest to Him in status is the just leader. And the most hated of people to Allah and the furthest from Him in status is the oppressive leader" (At-Tirmidhi:1329)

The first Caliph of Islam, Abubakar As-Siddeeq (May Allah be pleased with him) applied the principle of equality when he was appointed, Mujahid (2012) quoted Abubakar when he addressed the companions (May Allah be pleased with them) as follows:

"O people, I have indeed been appointed over you, though I am not the best among you. If I do well, then help me; and if I act wrongly then correct me.. Truthfulness is synonymous with fulfilling the trust, and lying is tantamount to treachery. The weak among you is deemed strong by me, until I return to them that which is rightfully theirs Insha Allah (Allah willimg). And the strong among you is deemed weak by me until I take from them what is rightfully (someone else's), insha Allah."

Islam encourages equal right in the use of Government facilities and prohibits unequal distribution of Government wealth and favouritism. Prophet Muhammad (PBUH) indicated that it is one of the terrible things that will happen prior to the day of judgement (Sunan At-Tirmidhi: 2211 ) Sheikh Abdullahi Bn Fodio reported that, a leader should give everybody the right he owes even if that right will be against the leader or some persons among his subjects (Luwa, 2013). Also Al-Quran says; "And be fair: for Allah loves those who are fair (and just)" (Al-Quran, 49:9)

Sallabi (2010) reported that, the fourth Caliph of Islam Ali ibn Abi Talib was known to be following the general principle of equality confirmed by Islam in his administration. Allah says: "O mankind! We have created you from a male and a female, and made you into nations and tribes, that you may know one another. Verily, the most honourable of you with Allah is that [believer] who has At-Taqwa [i.e. he is one of the Muttaqoon (the pious)]. Verily, Allah is All-Knowing, All-Aware” (Qur'an 49: 13) 
Ali's implementation of this principle is the best model. He gave to the people equally without allowing himself to take anything from this wealth except as much as he gave to other people. Ali also gave stipends to his opponents just as he gave to others, and He did not give precedence to a nobleman over a commoner or to an Arab over a non-Arab (Sallabi, 2010). Ali (2016) said that, the important condition of Islam is that there should be perfect fairness and justice and respect for the highest principles, because Islam takes account of every just and legitimate interest without separating spiritual from temporal matters.

H1 Corruption is significantly related to inefficiency in the public service

\section{Methodology}

Sample of this study comprises of senior staff of Local Government Service Commission of Sokoto State, Nigeria. Survey questionnaire was administered to 190 employees through simple random sampling and only 101 were used as indicated in Table 1 . To improve the response rate, the questionnaires were delivered to the respondents by hand and collected by hand on a scheduled pick-up date. PLS-SEM 3.0 was used for data analysis. This study classified responses according to a five-point Likert scale ranging from 1 (strongly disagree) to (strongly agree). Partial least square structural equation model (PLS-SEM) method was used and found suitable by this study because, the research model entails considerable complexity regarding the type of relationships in hypotheses. This study also uses latent variables' scores in the consequent analysis for predictive purposes. This study concurrently uses SmartPLS 3 software (Hair et al. 2014).

Table 1 Demographic Profile of the Total Sample

\begin{tabular}{|l|c|c|}
\hline Characteristics & Frequency & Percentage\% \\
\hline Gender & 82 & 85.4 \\
\hline Male & 14 & 14.6 \\
\hline Female & & 75.2 \\
\hline Marital Status & 73 & 21.8 \\
\hline Married & 20 & 3.0 \\
\hline Single & 3 & \\
\hline Divorced & & 30.2 \\
\hline Age & 29 & 31.3 \\
\hline $30-39$ & 30 & 38.5 \\
\hline $40-49$ & 37 & 100 \\
\hline $50-59$ & & 34.4 \\
\hline Category & 96 & 58.3 \\
\hline Senior staff & & 7.3 \\
\hline Educational level & 33 & \\
\hline Diploma/NCE & 56 & \\
\hline Degree/HND & 7 & \\
\hline Postgraduate Degree & & \\
\hline
\end{tabular}

\section{Results}

The PLS model analysis covers two stages: (1) assessment of reliability and validity of measurement model and (2) evaluation of structural model.

\subsection{MEASUREMENT MODEL}

The reflective measurement model assesses model's reliability and validity which involves indicators item loading, composite reliability, convergent validity and discriminant validity. Convergent validity is the level to which items accurately represent the intended latent construct and certainly correlate with other measures of the similar latent construct is evaluated by examining the AVE of each latent construct, as recommended by Hair et al. (2014). To achieve adequate convergent validity, the rule of thumb indicates that only items with loadings between 0.40 and above, and items with Average Variance Extracted (AVE) of 0.50 and above should be retained as suggested by Hair et al. (2017) and Chin (1998). Also, Bagozzi and Yi (1988) 
and (Hair, Ringle and Sarstedt (2011) recommended that the composite reliability coefficient should be at least 0.70 or more.

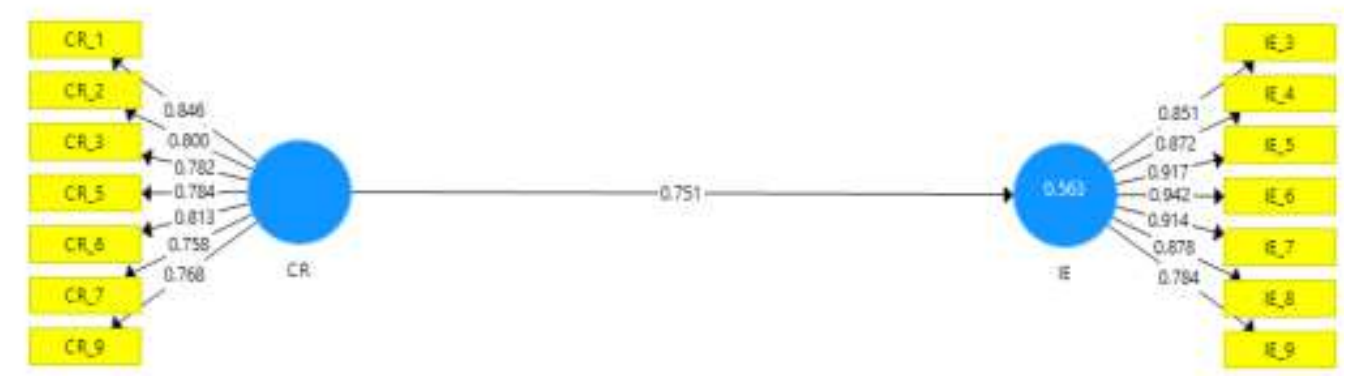

Figure 2: Measurement Model

Result shows that all the requirements were met in assessing measurement model. Firstly, reflective individual items are reliable, because all standardised loadings are above 0.6 as indicated in figure 2 and Table 2 respectively. Accordingly, the individual item reliability is satisfactory (Hair, Hult, Ringle, \& Sarstedt, 2017). Secondly, the composite reliabilities of all reflective constructs are greater than 0.7 indicating that the requirement of construct reliability is met (Leal-Rodríguez, Eldridge, Roldán, LealMillán, \& Ortega-Gutiérrez, 2015).

As indicated in Table 2, the convergent validity is achieved by the latent variables since their average variance extracted (AVE) exceeds 0.5 level (Fornell and Larcker 1981). Also, Table 3 confirms that all the variables met the requirement of discriminant validity. This is achieved from a comparison of the square root of AVE versus the corresponding latent variable correlations. For discriminant validity to be satisfactory, diagonal elements should be significantly greater than off-diagonal elements in the corresponding columns and rows (Roldán and Sánchez-Franco 2012)

Table 2: Measurement Model: Reliability and Convergent Validity

\begin{tabular}{|c|c|c|c|c|}
\hline Construct & Loadings & Cronbach's Alpha & Composite Reliability & $\begin{array}{l}\text { Average Variance } \\
\text { Extracted (AVE) }\end{array}$ \\
\hline IE_3 & 0.851 & 0.951 & 0.960 & 0.776 \\
\hline IE_4 & 0.872 & & & \\
\hline IE_5 & 0.917 & & & \\
\hline IE_6 & 0.942 & & & \\
\hline IE_7 & 0.914 & & & \\
\hline IE_8 & 0.878 & & & \\
\hline IE_9 & 0.784 & & & \\
\hline CR_1 & 0.846 & 0.902 & 0.922 & 0.629 \\
\hline CR_2 & 0.800 & & & \\
\hline CR_3 & 0.782 & & & \\
\hline CR_5 & 0.784 & & & \\
\hline CR_6 & 0.813 & & & \\
\hline CR_7 & 0.758 & & & \\
\hline CR_9 & 0.768 & & & \\
\hline
\end{tabular}

Table 3: Discriminant Validity (Fornell \& Larcker, 1981)

\section{Construct}

CR
IE 


\begin{tabular}{|c|c|c|}
\hline IE & $\mathbf{0 . 8 8 1}$ & $\mathbf{0 . 7 9 3}$ \\
\hline CR & 0.751 & \\
\hline
\end{tabular}

Table 4: Cross Loadings

\begin{tabular}{|l|r|r|}
\hline Construct & IE & CR \\
\hline IE_3 & $\mathbf{0 . 8 5 1}$ & 0.657 \\
\hline IE_4 & $\mathbf{0 . 8 7 2}$ & 0.648 \\
\hline IE_5 & $\mathbf{0 . 9 1 7}$ & 0.664 \\
\hline IE_6 & $\mathbf{0 . 9 4 2}$ & 0.695 \\
\hline IE_7 & $\mathbf{0 . 9 1 4}$ & 0.663 \\
\hline IE_8 & $\mathbf{0 . 8 7 8}$ & 0.638 \\
\hline IE_9 & $\mathbf{0 . 7 8 4}$ & 0.656 \\
\hline CR_1 & 0.566 & $\mathbf{0 . 8 4 6}$ \\
\hline CR_2 & 0.541 & $\mathbf{0 . 8 0 0}$ \\
\hline CR_3 & 0.559 & $\mathbf{0 . 7 8 2}$ \\
\hline CR_5 & 0.612 & $\mathbf{0 . 7 8 4}$ \\
\hline CR_6 & 0.689 & $\mathbf{0 . 8 1 3}$ \\
\hline CR_7 & 0.585 & $\mathbf{0 . 7 5 8}$ \\
\hline CR_9 & 0.591 & $\mathbf{0 . 7 6 8}$ \\
\hline
\end{tabular}

In addition, as stated earlier, discriminant validity can also be achieved by comparing the indicator item loadings with cross-loadings. To ascertain satisfactory discriminant validity, Chin (1998) recommended that all the indicator item loadings should be greater than the cross-loadings. Table 4 compares the indicator item loadings with other indicators. All indicator item loadings are higher than the cross-loadings, recommending acceptable discriminant validity for further analysis. Therefore, in this study, all the criteria for attaining discriminant validity are achieved.

\subsection{Structural Model}

The assessment of structural model includes, testing of path coefficient (hypothesis), assessment of Rsquare, evaluation of effect size and assessment of predictive relevance of the study model. The study achieved all the requirement of structural model. Therefore, bootstrapping procedure was used in assessing structural model (Figure 3). Table 5 indicates the bootstrapping results which provides t-values that permit the assessment of statistical significance relationship in the research model (Ramayah, Cheah, Chuah, Ting, \& Memon, 2017). In this situation, the results significantly support the hypothesis, which defines the direct relationship of Corruption (CR) and Inefficiency (IE) (Beta $=0.751 ; \mathrm{t}=20.715)$.

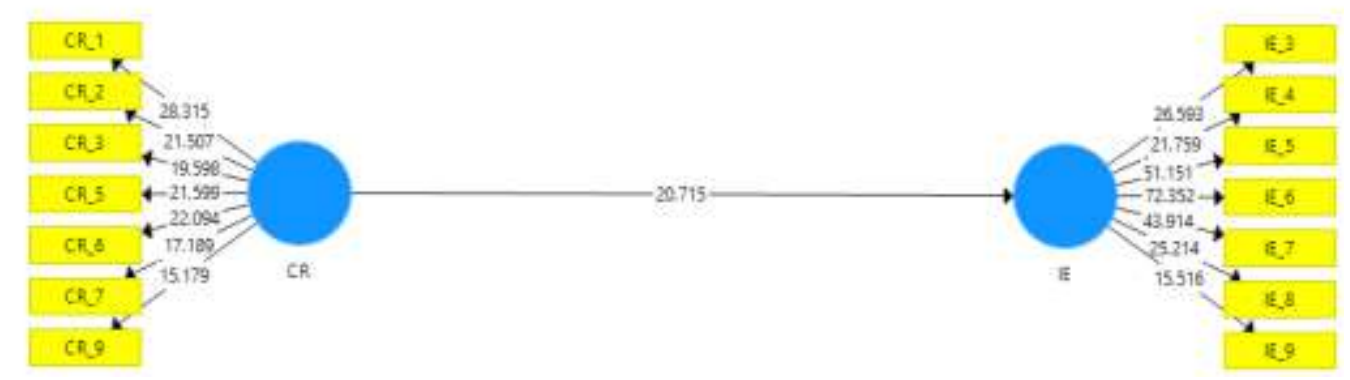


Table 5: Result of Hypothesis Testing

\begin{tabular}{|l|c|c|c|c|c|}
\hline Hypothesis & Beta & Standard Error & T Statistics & P Values & Decision \\
\hline CR -> IE & 0.751 & 0.036 & 20.715 & $\mathbf{0 . 0 0 0}$ & Supported \\
\hline
\end{tabular}

In addition, the $R^{2}$ represent the predictive accurateness of the model, it signifies the collective effects of the exogenous latent constructs on the endogenous latent construct as proposed by Hair et al., (2014). Table 6 indicates the variance explained (R2) in the endogenous variable and the path coefficients for the study model.

Table 6: Coefficient of Determination

\begin{tabular}{|c|c|}
\hline Construct & R Square \\
\hline IE & 0.563 \\
\hline
\end{tabular}

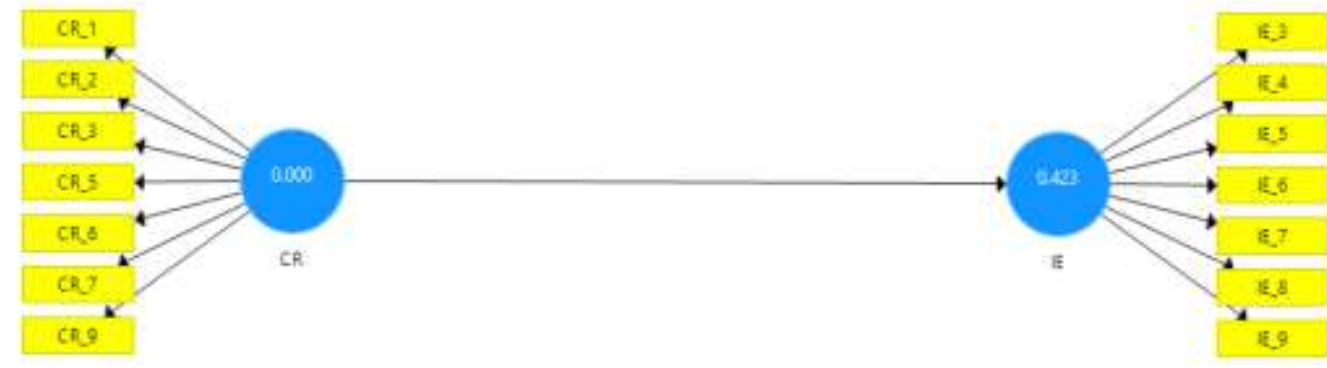

Figure 4: Blindfolding

Also, in Table 7 and Figure 4, the result from blindfolding and Predictive relevance $(Q 2)$ of the latent endogenous construct is higher than zero. This clearly shows that the model has predictive relevance (Chin, 1998; Hair et al., 2014; Hayes et al., 2009)

Table 7: Predictive Relevance

\begin{tabular}{|c|c|c|c|}
\hline Total & SSO & SSE & $\mathbf{Q}^{2}=\mathbf{1 - S S E} /$ SSO \\
\hline Inefficiency & 770.000 & 444.355 & 0.423 \\
\hline
\end{tabular}

\section{Conclusions And Recommendations}

This paper discusses the effect of corruption on inefficiency in the Nigerian Public service, the Islamic approach. Primary data was analysed to establish the relationship between corruption and inefficiency. The research findings established that inefficiency that bedevilled the public service is as a result of corruption. All corrupt behaviours and actions are forbidden, unacceptable and intolerable in Islam no matter how small or insignificant they may be. The term corruption in the Holy Qur'an and Sunnah of the Prophet Muhammad (PBUH) has a wide meaning that includes abuse of power or misuse of public office, bribery, cheating, cronyism, nepotism, favouritism, theft, inefficiency and unprofessionalism in society, misuse of politics, economics and the environment. Therefore, in exercising ethical conduct, leaders should be trustworthy in keeping the responsibilities entrusted on them. Leaders are expected to lead by example and also educate the public on the implication of corruption and also enforce the rules and regulations provided for eradication of corruption in the public service. Furthermore, Islamic work ethics should be maintained so as to have a decent public service in Nigeria. Future research is suggested.

\section{References}

1. Ali, A. R. A. H., Noordin, K. Bin, \& Achour, M. (2018). The Islamic approach of obligations in mutual relations between employee and employer. International Journal of Ethics and Systems, 
34(3), 338-351. https://doi.org/10.1108/IJOES-12-2017-0227

2. Ali, A. Y. (2012). The Meaning of The Holy Qur'an: Text, Translation and Commentary (New). Kuala Lumpur Malaysia: Islamic Book Trust.

3. Andvig, J. C., Fjeldstad, O. H., Amundsen, I., Sissener, T., \& Søreide, T. (2001). Corruption: A review of contemporary research. Report - Chr. Michelsen Institute.

4. Arafa, M. (2012). Corruption and Bribery in Islamic Law: Are Islamic Ideals Being Met in Practice? Annual Survey of International \& Comparative Law, 18(1).

5. Arowolo, D. (2012). Ethics, Motivation and Performance in Nigeria's Public Service, 2(5), 37-43.

6. Attahiru, M. S. (2021). Justice and Islamic Work Ethics A Framework For Leaders of Public and Private Organizations. International Journal of Research, 9(11), 214-226.

https://doi.org/10.29121/granthaalayah.v9.i11.2021

7. Ayobolu, J. (2006). EFCC, Corruption And The Due Process.

8. Bagozzi, R. P., \& Yi, Y. (1988). On the Evaluation of Structural Equation Models. Journal of the Academy of Marketing Science. https://doi.org/10.1177/009207038801600107

9. Chandio, A. R., \& Chandio, M. A. (2021). An Islamic Perspective On Public Administration: Concept And Official Ethics. International Journal of Academic Multidisciplinary Research, 5(6), 255-260.

10. Chandio, A. R., Iqbal Ameen Brohi, S. A., Ali, M., \& Gadhi, G. N. (2019). Administrative Ethics With Special Reference Toislam. Global Scientific Journals, 7(7), 913-923.

11. Chin, W. (1998). The partial least squares approach to structural equation modeling. Modern Methods for Business Research, 295(2), 295-336. https://doi.org/10.1016/j.aap.2008.12.010

12. EFCC. (2019). EFCC Tasks Corps Members to Shun Corruption, Cybercrime.

13. Fornell, C., \& Larcker, D. F. (1981). Structural Equation Models with Unobservable Variables and Measurement Error: Algebra and Statistics. Journal of Marketing Research, 18(3), 382-388. https://doi.org/10.2307/3150980

14. Hair, J. F. J., Hult, G. T. M., Ringle, C. M., \& Sarstedt, M. (2017). A primer on partial least squares structural equation modeling (PLS-SEM) (second). Los Angeles: SAGE Publications.

15. Hair, J. F. J., Hult, G. T. M., Ringle, C., \& Sarstedt, M. (2014). A Primer on Partial Least Squares Structural Equation Modeling (PLS-SEM). Long Range Planning (Vol. 46). https://doi.org/10.1016/j.lrp.2013.01.002

16. Hair, J. F., Ringle, C. M., \& Sarstedt, M. (2011). PLS-SEM: Indeed a Silver Bullet. Journal of Marketing Theory and Practice, 19(2), 139-152. https://doi.org/10.2753/MTP1069-6679190202

17. Hair Jr, F. J., Sarstedt, M., Hopkins, L., \& Kuppelwieser, G. V. (2014). Partial least squares structural equation modeling (PLS-SEM): An emerging tool in business research. European Business Review, 26(2), 106-121. https://doi.org/http://dx.doi.org/10.1108/BIJ-10-2012-0068

18. Hayes, A. F. (2009). Beyond Baron and Kenny: Statistical Mediation Analysis in the New Millennium. Communication Monographs, 76(4), 408-420.

19. Ijewereme, O. B. (2015). Anatomy of Corruption in the Nigerian Public Sector: Theoretical Perspectives and Some Empirical Explanations. SAGE Open, 5(2). https://doi.org/10.1177/2158244015581188

20. Khallyl, A. (2007). The English Translation of Jami' At-Tirmidhi. (A. Khaliyl, Ed.) (First). Riyadh Saudi Arabia: Darussalam.

21. Leal-Rodríguez, A. L., Eldridge, S., Roldán, J. L., Leal-Millán, A. G., \& Ortega-Gutiérrez, J. (2015). Organizational unlearning, innovation outcomes, and performance: The moderating effect of firm size. Journal of Business Research, 68(4), 803-809. https://doi.org/10.1016/j.jbusres.2014.11.032

22. Luwa, A. B. (2013). Selected writings of Sheikh Abdullahi Bn Fodiyo (A guide to the Sultan and other brothers). (S. Musa, Ed.). Gusau, Nigeria: Iqra' publishing house, Gada-biyui.

23. Mohammed, U. (2013). Corruption in Nigeria: A Challenge to Sustainable Development in the Fourth Republic. European Scientific Journal, 9(4), 118-137.

24. Muhammad, M. Z., Yusof, M. F., Amin, H., \& Chowdhury, M. S. R. (2012). Islamic Business Ethics in Small and Medium Enterprises (SMEs): An analysis. In 3rd International Conference on Business and Economic Research (3rd ICBER 2012) Proceedings. Bandung, Indonesia. Retrieved from http://umkeprints.umk.edu.my/491/1/Paper 1.pdf

25. Mujahid, A.-M. (2012). Golden Stories of Abubakar As-Siddeeq. Riyadh: Dar-us-Salam Publications. 
26. Nations, U. (2021). UNODC's Action against Corruption and Economic Crime.

27. Nwankwo, Odi, F. (2014). Impact of Corruption on Economic Growth in Nigeria. Mediterranean Journal of Social Sciences, 5(6).

28. Nweke, M. (2019). Various dimensios of Corruption in Nigeria: A case of the Nigerian Public Sector. Josas, 3(1), 1-11.

29. Omisore, B. O. (2015). Work ethics, values, attitudes and performance in the nigerian public service : issues, challenges and the way forward. Journal of Public Administration and Governance, 5(1), 157-172.

30. Osawe, C. O. (2015). Nigerian Public Service Performance in a Dysfunctional Ecology: Issues, Challenges and the Way Forward. Review of Public Administration and Management, 3(7), 45-57.

31. Ramayah, T., Cheah, J., Chuah, F., Ting, H., \& Memon, M. A. (2017). Partial Least Squares Structural Equation Modeling (PLS-SEM) Using SmartPLS 3.0 An updated and practical guide to statistical analysis (First). Kuala Lumpur Malaysia: Pearson Malaysia Sdn Bhd.

32. Roldán, J. L., \& Sánchez-Franco, M. J. (2012). Variance-Based Structural Equation Modeling: Guidelines for Using Partial Least Squares in Information Systems Research. In Research Methodologies, Innovations and Philosophies in Software Systems Engineering and Information Systems (pp. 193-221).

33. Salihu, H. A. (2020). Combating corruption in the Nigerian Civil Service: An empirical assessment of treasury single account (TSA) policy. Journal of Money Laundering Control, 23(1), 267-280.

34. Sallabi, A. M. (2010). ALI ibn Abi Talib. International Islamic Publishing House. https://doi.org/10.1017/CBO9781107415324.004

35. Salleh, M. J., \& Mohamad, N. A. (2012). Islamic Principles of Administration: Implications on Practices in Organization. In Technology, Science, Social Sciences and Humanities International Conference (pp. 14-15). One Helang Hotel, Lankawi.

36. Siddiqi, M. N. (2004). Riba, bank interest and the rationale of its prohibition. Jeddah Saudi Arabia: Islamic research and training institute Islamic development bank.

37. Tanzi, V. (1998). Corruption Around the World: Causes, Consequences, Scope and Cures.

38. Transparency, I. (2022). What is Corruption?

39. Walyben. (2022). Reasons why the Civil Service Operations are ineffective and inefficient.

40. Yusuf, M. K. (2013). Selected writings of Sultan Muhammadu Bello (Principles of leadership). (Y. A.B, Ed.). Gusau, Nigeria: Iqra' publishing house, Gada-biyui. 